\title{
NEGOTIATION INTERMEDIARIES DAN IDENTIFIKASI PENYELESAIAN SENGKETA HAK ATAS TANAH MASYARAKAT ADAT CEK BOCEK SALESEK REEN SURY DI KABUPATEN SUMBAWA

\author{
NEGOTIATION INTERMEDIARIES AND IDENTIFICATION OF \\ DISPUTES ON LAND RIGHTS SETTLEMENT CEK BOCEK \\ SELESEK REEN SURY INDIGENOUS PEOPLE IN SUMBAWA \\ REGENCY
}

\author{
M. Syukron Anshori, \\ Fakultas Ilmu Komunikasi Universitas Brawijaya \\ Email: oriemuhammad31@gmail.com \\ Rachmat Kriyantono \\ Fakultas Ilmu Komunikasi Universitas Brawijaya \\ Email : rachmat_kr@ub.ac.id \\ Maulina Pia Wulandari \\ Fakultas Ilmu Komunikasi Universitas Brawijaya \\ Email : mpiawulandari@gmail.com
}

Naskah diterima : 11/11/2017; direvisi : 19/12/2017; disetujui : 28/12/2017

\begin{abstract}
The aim of this research is to propose a form of communication patterns in conflict situation in the affair of customary land dispute on Cek Bocek Salesek Reen Sury community in Sumbawa Regency. This research utilized constructive approach, qualitative research method. To get accurate data from informants, the data was collected by indepth interview and overt-participant; and the participants known the presence of the researcher in the form of interaction and conversation (Kriyantono, 2014: 111). The result of the research shows that there are three conflicts involving indigenous people of Cek Bocek Salesek Reen Sury concerning customary land dispute. The first is indigenous peoples' conflicts with PT. Newmont Nusa Tenggara, the second is indigenous peoples' conflict with Sumbawa District Government and the third is indigenous peoples' conflict with Lembaga Adat Tana' Samawa (LATS). The dominance of Local Government and the presence of Lembaga Adat Tana' Samawa (LATS) through PERDA no.9 year 2015 further complicate the existence of other indigenous peoples in Sumbawa regency including Cek Bocek Salesek Reen Sury. Based on the result of communication analysis, this kind of conflict situation requires communication pattern of intermediary's negotiation to determine effective communication steps on indigenous people of Cek Bocek Salesek Reen Sury in Sumbawa Regency.
\end{abstract}

Keywords : Communication Pattern, Negotiation, Conflict, Indigenous People, Land Dispute. 


\begin{abstract}
Abstrak
Tujuan dilakukannya penelitian ini adalah menawarkan bentuk pola komunikasi pada situasi konflik dalam urusan sengketa tanah adat pada masyarakat Cek Bocek Salesek Reen Sury di Kabupaten Sumbawa. Penelitian ini menggunakan pendekatan konstruktif dengan metode penelitian kualitatif. Metode pengumpulan data dilakukan dengan wawancara mendalam (indepth interview) dan observasi partisipan (overt-participant) guna mendapatkan data yang akurat dari informansesuai dengan kebutuhan dan pada situasi orang-orang yang diteliti mengetahui kehadiran peneliti dalam bentuk interaksi dan percakapan (conversation). Hasil penelitian menunjukkan terdapat tiga konflik yang melibatkan masyarakat adat Cek Bocek Salesek Reen Sury dengan satu objek pertanahan. Pertama, konflik masyarakat adat dengan PT. Newmont Nusa Tenggara. Kedua, konflik masyarakat adat dengan Pemerintah Daerah Kabupaten Sumbawa dan ketiga, konflik masyarakat adat dengan Lembaga Adat Tana' Samawa (LATS). Kuatnya dominasi Pemerintah Daerah dan hadirnya Lembaga Adat Tana Samawa (LATS) melalui PERDA No. 9 Tahun 2015 semakin mempersulit eksistensi dan keberadaan masyarakat adat lainnya di Kabupaten Sumbawa termasuk masyarakat adat Cek Bocek Salesek Reen Sury. Berdasarkan hasil analisis komunikasi, situasi konflik semacam ini membutuhkan pola komunikasi negosiasi intermediaries untuk menentukan langkah komunikasi yang efektif pada masyarakat adat Cek Bocek Salesek Reen Sury di Kabupaten Sumbawa.
\end{abstract}

\title{
Kata Kunci: Pola Komunikasi, Negosiasi, Konflik, Masyarakat adat, Sengketa Tanah.
}

\section{PENDAHULUAN}

Sengketa tanah perlu dilihat sebagai sengketa hak atau adanya perebutan hak atas kepemilikan tanah yang jelas maupun kepemilikan tanah yang tidak jelas, atau dapat dikatakan sengketa tanah terjadi karena adanya kepentingan dan hak. "Sengketa hak atas tanah adalah perebutan hak bukan perebutan tanah, sehingga yang diperebutkan adalah status hak yang melekat pada obyek yang disebut tanah. Hak yang melekat pada tanah bisa saja berupa hak milik, hak guna usaha, hak guna bangunan dan hak-hak yang lainnya"1.

Ketidakpastian tentang hak milik adat telah melahirkan banyak perselisihan antara

1 S. Mu'adi.: "Penyelesaian Sengketa Hak Atas Tanah Perkebunan Melalui Cara Non Litigasi (Suatu Studi Litigasi Dalam Situasi Transisional", Disertasi Program Pasca Sarjana Universitas Diponegoro, 2008, hal. xix para pemangku kepentingan atas hak tanah di Indonesia, konflik lahan atau sengketa tanah antara pemerintah dan masyarakat adat telah terjadi sejak lama ${ }^{2}$. Bahkan sengketa hak atas tanah tidak akan pernah berakhir dan akan terus mengalami perkembangan dari waktu ke waktu yang akan melibatkan banyak kesatuan masyarakat, antara lain sengketa antar kesatuan masyarakat hukum adat, masyarakat dengan pemerintah, masyarakat dengan institusi lain non pemerintah dan antar masyarakat itu sendiri ${ }^{3}$.

Masyarakat adat saat ini telah terperangkap dalam konflik dan kontestasi dikarenakan tidak kuatnya peraturan untuk melindungi hak-hak adat yang menjadi kelemahan utama dari sistem hukum di

2 T. Kurnia. 2007.: "The Struggle Over Land Rights: A Study of Indigenous Property Rights In Indonesia". Dissetation: University Of Washington.

${ }^{3}$ S. Mu'adi.Op.Cit. 
Indonesia ${ }^{4}$. Apalagi hukum negara dianggap memiliki posisi yang lebih tinggi dibandingkan dengan hukum adat, sehingga seringkali negara mengambil keputusan sepihak tanpa melibatkan masyarakat lokal yang menggantungkan hidupnya dengan sumber daya alam tersebut 5 .

Selain persoalan hukum dan yuridis, konflik yang menyangkut persoalan tanah kerap terjadi karena persoalan tumpang tindih penggunaan lahan antara masyarakat dan pemerintah atau perusahaan ${ }^{6}$. Tumpang tindih ini tidak lepas dari lemahnya sistem hukum dibidang pertanahan. Dikutip dari situs resmi Badan Pertanahan Nasional Republik Indonesia (BPN RI) setidaknya terdapat 582 produk hukum yang mengatur masalah pertanahan di Indonesia ${ }^{7}$. Dari banyaknya produk hukum tersebut, masih banyak yang tumpang tindih dan kontradiktif. Bahkan beberapa masalah pertanahan masih tidak diatur sama sekali dalam perundang-undangan di Indonesia sehingga kontroversi hukum yang terjadi di Indonesia telah merusak tatanan kehidupan masyarakat adat saat ini ${ }^{8}$.

${ }^{4}$ F.N, Rachman, dan M. Siscawati. Masyarakat Hukum Adat Adalah Bukan Penyandang Hak, Bukan Subjek Hukum, dan Bukan Pemilik Wilayah Adatnya. Wacana Jurnal Transformasi Sosial (33), 2014, 3-23.

${ }^{5}$ M.A, Larson. "Measuring A Company Reputation In A Crisis Situation: An Ethnography Approach On The Situational Crisis Communication Theory". International Jounal of Business and Social Science 3(9), 2012, 214-223.

6 M. M. Mantiri. "Analisis Konflik Agraria Di Pedesaan (Suatu Studi Di Desa Lemoh Barat Kecamatan Tombariri)". Governance: 5 (1), 2013, 19 .

${ }^{7}$ Badan Pertanahan Nasional Republik Indonesia. Layanan Public Program Penanganan Kasus Pertahanan. $\quad$ http://www.bpn.go.id/layananpublik/program/penanganan-kasus-pertanahan)

(Diakses Pada 27 Januari 2017.

8 S. Butt, N. David, dan N. Laws. "Looking Forward: Local Dispute Resolution Mechanisms In Timor Leste". Australian Legal Resources International 09/33: 2009,121.
Tumpang tindih ini menyebabkan sengketa yang melibatkan semua tingkat lembaga mulai dari lembaga daerah hingga lembaga tingkat pusat ${ }^{9}$. Sehingga keberadaan masyarakat adat dianggap sebagai penyerobotan lahan dan perusakan mata pencaharian, hal ini sebagai konsekuensi masyarakat adat yang tidak diakui dan dianggap sebagai musuh negara ${ }^{10}$. Hal ini terjadi karena belum ada penegasan pengakuan dan penghormatan terhadap hakhak yang dimiliki komunitas lokal, termasuk komunitas adat sebagai pihak yang paling terkena dampaknya. Sehingga menyebabkan terjadinya ketimpangan akses penguasaan dan pengelolaan sumber daya agraria dikarenakan prinsip "menguasai" oleh negara masih sangat kental ${ }^{11}$. Ketidakpastian tentang hak milik tanah dapat memunculkan perselisihan konflik lahan atau sengketa antara pemerintah, perusahaan dan masyarakat lokal. Perusahaan, diperlakukan dengan cara yang sama seperti pemerintah karena perusahaan mendapatkan izin dari pemerintah untuk mengolah tanah ${ }^{12}$. Situasi ketidakpastian ini diartikan sebagai legal pluralism ${ }^{13}$ atau

${ }^{9}$ A. Bedner, dan S. Van Huis. "The Return Of The Native In Indonesian Law: Indigenous Communities In Indonesian Legislation. Bijdragen Tot De Taal-, LandEn Volkenkunde". Journal of The Humanities And Social Sciences Of Southeast Asia 164(2), 2008, 165193.

${ }^{10}$ J. Davidson, dan D. Henley. "The Revival of Tradition In Indonesian Politics: The Deployment Of Adat From Colonialism To Indigenism". New York: Routledge, 2007

${ }^{11}$ S. Mu'adi. Doctoral Dissertation: "Penyelesaian Sengketa Hak Atas Tanah Perkebunan Melalui Cara Non Litigasi (Suatu Studi Litigasi Dalam Situasi Transisional", Program Pasca Sarjana Universitas Diponegoro, 2008, hal. cclxvi

${ }^{12}$ T. Kurnia. Doctoral Dissertation: "The Struggle Over Land Rights: A Study Of Indigenous Property Rights In Indonesia". Washington: University Of Washington, 2007

13 A. M. Larson. "Measuring A Company Reputation In A Crisis Situation: An Ethnography Approach On The Situational Crisis Communication 
adanya situasi dua atau lebih sistem hukum. Maka dapat dipastikan akan ada klaim hak atas tanah/hutan dari masing-masing kelompok yang hanya mengakui keberadaan satu hukum demi kepentingannya ${ }^{14}$. Walaupun terdapat kenyataan bahwa tanah diperuntukkan sebagai bagian dari ruang hidup dan kehidupan masyarakat adat, wilayah adat yang terdiri dari berbagai peruntukan dan penggunaan lahan, seperti pemukiman, ladang dan kebun serta tempattempat keramat termasuk hutan adat yang dikelola langsung oleh masyarakat adat ${ }^{15}$.

Dengan dalih pembangunan, keadaan semacam ini akan mengabaikan keberadaan masyarakat lokal, sehingga dapat memicu terjadinya gejolak dan sengketa hak atas tanah sehingga menyebabkan ketidakjelasan kekuasaan atas tanah dan hutan yang sering kali diikuti dengan kekerasan bahkan tidak jarang melahirkan korban jiwa ${ }^{16}$. Hal ini sebagai contoh dari hubungan konflik yang terjadi antara masyarakat adat dan perusahaan pertambangan di seluruh dunia $^{17}$. Bahkan di banyak negara, hak-hak masyarakat adat telah direbut melalui pengambilalihan atau privatisasi tanah oleh negara. Sehingga yang terjadi, banyak

Theory". International Jounal of Business and Social Science 3(9). 2012, 214-223.

${ }^{14}$ K. von Benda-Beckmann. "Forum Shopping And Shopping Forums: Dispute Processing In A Minangkabau Village In West Sumatra". The Journal Of Legal Pluralism And Unofficial Law 13(19), 1981, 117-159.

${ }^{15}$ J. Gunawan.. "Implementasi Permendagri NO 52 Tahun 2014 Tentang Pedoman Pengakuan Dan Perlindungan Masyarakat Hukum Adat (Studi Terhadap Keberadaan Masyarakat Adat Cek Bocek Selesek Reen Suri Di Kabupaten Sumbawa)". Disertasi: Program Pascasarjana Unram, 2015

${ }^{16}$ S. Mu'adi. Op.Cit.

17 G. Whiteman, dan K. Mamen. "Examining Justice And Conflict Between Mining Companies And Indigenous Peoples Cerro Colorado And The NgabeBugle In Panama". Journal Of Business And Management 8 (3), 2002, 293. diantara mereka dihadapkan pada konflik urusan pertanahan ${ }^{18}$.

Di Desa Lawin, Kecamatan Ropang, Kabupaten Sumbawa, terdapat sekelompok masyarakat adat yang hidup secara turun temurun yang dikenal sebagai masyarakat adat Cek Bocek Selesek Reen Sury, masyarakat adat ini telah hidup secara turun temurun sejak tahun 1512 hingga hari ini ${ }^{19}$. Kehidupan masyarakat adat Cek Bocek Selesek Reen Sury yang turun temurun ini dibuktikan dengan eksistensi sosial budaya yang ditunjukkan berdasarkan kebiasaannya. Konsep kebudayaan yang turun ke pola perilaku suatu kelompok masyarakat melalui kebiasaan atau cara hidup $^{20}$. Sebuah penegasan hak atas tanah yang dilakukan oleh kelompok masyarakat adat Dayak di Kalimantan yang berkeyakinan bahwa "Tanah adalah hidup dan nafas kami", di Papua Barat hampir seluruh masyarakat adat meyakini bahwa "Tanah kita, hidup kita"21. Sementara pada 2011 lalu, ungkapan penegasan hak masyarakat adat Cek Bocek Salesek Reen Sury disampaikan oleh Datu Sukanda RHD selaku ketua adat: "Ada tidaknya Newmont, kami tetap hidup di wilayah adat"22.

Landasan yuridis yang mengatur masalah keagrariaan/pertanahan tidak sepenuhnya dijalankan secara konsekuen dengan berbagai alasan, sehingga menimbulkan masalah pertanahan dan

${ }^{18}$ B. Wehrmann. 2008 "Land Conflicts: A Practical Guide To Dealing With Land Disputes". Eschborn: Gtz.

${ }^{19} \mathrm{~J}$. Gunawan. Op.Cit.

20 J. P. Spradley. 2016 "The Ethnographic Interview". United State of America: Waveland Press..

21 P. K. Erari. 1999. "Tanah Kita, Hidup Kita: Hubungan Manusia Dan Tanah Di Irian Jaya Sebagai Persoalan Teologis: Eko Teologi Dalam Prespektif Melanesia”. Pustaka Sinar Harapan.

22 Anindita. F. 2015. "Masyarakat Adat, Penguasaan Hutan Adat dan Konsesi Pertambangan Masyarakat Adat Cek Bocek Vs Newmont Nusa Tenggara”. Working Paper Sajogyo Institute2: 1-24. 
menciptakan berbagai macam konflik di masyarakat ${ }^{23}$. Sementara itu, dalam pandangan hukum adat atau hak milik komunal diakui dan berbagai kategori hak atas tanah termasuk hak kepemilikan, eksploitasi, bangunan dan hak pakai selama tidak bertentangan dengan hukum nasiona ${ }^{24}$. Selain itu, minimnya pemahaman masyarakat terkait hak kepemilikan atas tanah yang dipersepsikan berbeda menurut hukum negara juga menjadi akar konflik dalam masyarakat yang berawal dari perundang-undangan. Persoalan tanah juga sangat sulit dilepaskan dengan kepentingan dan kekuasaan, sehingga pada setiap kasus sengketa pertanahan, hampir selalu menyentuh sisi politik ${ }^{25}$

Berdasarkan pengamatan, kurangnya daya tawar masyarakat adat Cek Bocek Selesek Reen Sury secara politik menyebabkan proses penyelesaian menjadi berlarut-larut, terutama peraturan-peraturan yang bersentuhan langsung dengan pemerintah. Padahal pemerintah daerah memberi peranan penting dalam proses dan solusi sengketa tanah yang dipengaruhi oleh konteks sosial dan politik setempat ${ }^{26}$. Jadi, meskipun secara hukum dan de facto masyarakat adat ada dan eksis, namun karena lemahnya posisi tawar yang memadai secara politik dan bisnis karena dianggap menghalangi pembangunan, maka tidak jarang masyarakat adat mendapat tekanan-tekanan yang bersifat politis.

Kebanyakan kasus sengketa tanah di Indonesia tidak diselesaikan melalui pengadilan (litigasi), melainkan melalui proses negosiasi antara perusahaan dan warga yang menuntut dengan penengah

${ }^{23}$ E. Budiman. Peradilan Agraria Solusi Alternatif Penyelesaian Sengketa Agraria. Jurnal Hukum. 1 (01) , 2005, 74-81

${ }^{24} \mathrm{~J}$. Gunawan. Op.Cit.

${ }^{25}$ S. Mu'adi. Op.Cit.

${ }_{26}$ M. Sakai. Land Dispute Resolution In The Political Reform At The Time Of Decentralization In Indonesia. Antropologi Indonesia. 68, 2002, 40-56. pemerintah daerah. Oleh karenanya, penggunaan prinsip Itikad baik (good faith) harus dikedepankan dan menjadi hal yang paling fundamental dan sentral dalam penyelesaian suatu sengketa ${ }^{27}$. Selain itu, partisipasi kedua pihak juga penting dalam pengambilan keputusan, hal ini mengacu pada keterlibatan bersama dalam perencanaan dan pencapaian tujuan bersama ${ }^{28}$. Untuk mengatasi sengketa, pihak yang berselisih secara teoritis dapat menempuh empat tahapan proses penyelesaian sengketa alternatif (ADR) Salacuse $(2007)^{29}$ :

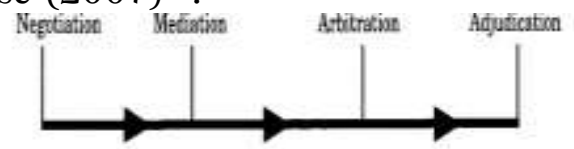

Gambar 1: Kontinum Penyelesaian Sengketa (Salacuse, 2007, h. 155)

Dalam langkah konflik kontinum di atas, pihak-pihak yang bersengketa akan semakin kehilangan kontrol dan tunduk pada pihak ketiga. Dengan mengandalkan negosiasi saja, pihak yang berselisih dapat lebih mudah mempertahankan kontrol mereka untuk menyelesaikan sengketa. Sementara dalam mediasi, kehadiran pihak ketiga akan mengubah dinamika dan memberikan pengaruh atas keputusankeputusan yang dihasilkan. Sedangkan proses arbitrase, akan memaksakan kedua pihak untuk tunduk pada putusan dan proses hukum yang berlaku. Dalam ajudukasi, yurisdiksi dan prosedur akan diputus berdasarkan hukum pengadilan, bukan atas keinginan-keinginan kedua pihak yang bersengketa. Bahkan secara lebih

${ }^{27}$ H. Adolf. 2004 Hukum Penyelesaian Sengketa Internasional. Bandung: RajaGrafindo Persada.

28 J.W. Driscoll. "Trust And Participation In Organizational Decision Making As Predictors of Satisfaction". The Academy Of Management Journal 21(1), 1978, 44-56.

29 J.W. Salacuse. Is There A Better WayAlternative Methods Of Treaty-Based, Investor-State Dispute Resolution: Fordham Int'l Lj 31: 138. 2007, hal. 155 
jauh, keempat proses ini menjadi satu kesatuan kontinum atau rangkaian struktur yang tidak terpisahkan ${ }^{30}$.

Dalam kajian ilmu komunikasi, secara khusus dijelaskan bahwa negosiasi dapat digunakan sebagai alat untuk mengidentifikasi dan membangun hubungan diantara pihak-pihak yang berkonflik ${ }^{31}$. Termasuk dalam mengatur strategi atau menemukan alternatif solusi dalam mencapai tujuan dan kesepakatan. Dengan kata lain, komunikasi menjadi titik tekan untuk menyelesaikan ataupun melakukan pengidentifikasian dalam situasi konflik. Terlebih lagi dalam hal merencanakan strategi dan memberi alternatif lain dalam mencapai sebuah tujuan. Sebagaimana tujuan negosiasi untuk menciptakan sesuatu yang baru yang tidak dilakukan sebelumnya atau untuk menyelesaikan masalah atau sengketa antara kedua pihak ${ }^{32}$. Dari penjelasan tersebut, dapat dikatakan negosiasi adalah sebagian upaya yang dilakukan antara pihak-pihak yang berkonflik dengan tujuan mencari jalan keluar untuk menyelesaikan pertentangan berdasarkan kesepakatan bersama.

Negosiasi sebagai salah satu alternatif menjadi prosedur penting dalam proses penyelesaian sengketa, Osi (2008) mendefinisikan negosiasi sebagai:

"Bargaining relationship between parties who have a perceived or actual conflict of interest. The participants voluntarily join in a temporary relationship designed to educate each other about their needs and interests, to exchange specific resources, or resolve less tangible issues such as the form their relationship will take in the future or the

\footnotetext{
${ }^{30}$ Ibid.

${ }^{31}$ L.L. Putnam, dan J.P. Folger. "Communication, Conflict, And Dispute Resolution The Study Of Interaction And The Development Of Conflict Theory". Communication Research, 15(4), 1988, 349-359.

${ }^{32}$ R.J. Lewicki, et.al., "Negotiation". $4^{\text {th }}$ ed, New York: Mcgraw-Hill Higher Education. 2003
}

procedure by which problems are to be solved"33.

Dari definisi tersebut, dapat dikatakan bahwa negosiasi adalah proses sukarela dari kedua pihak untuk menyelesaikan sengketa dengan itikad baik tanpa perlu melalui jalur pengadilan. Artinya, kedua pihak yang berselisih sama-sama mencari solusi untuk mengatasi masalah dan tanpa perantara pihak ketiga. karena dengan cara ini, para pihak dapat mengawasi prosedur penyelesaian sengketanya dan setiap penyelesaiannya didasarkan pada kesepakatan atau konsensus para pihak ${ }^{34}$.

Fenomena konflik sengketa tanah masyarakat adat cek bocek salesek reen sury tidak hanya dihadapkan dengan PT. Newmont Nusa Tenggara, namun juga melibatkan Pemerintah Daerah Kabupaten Sumbawa dan Lembaga Adat Tana' Samawa (LATS). Oleh karena itu, tujuan penulisan ini adalah untuk mengidentifikasi keterlibatan pihak-pihak terkait sengketa hak atas tanah pada masyarakat adat cek bocek salesek reen sury dan pola negosiasi pada situasi konflik.

Metode yang digunakan adalah metode deskriptif dan kualitatif. Untuk memperoleh data yang dibutuhkan, peneliti melaksanakan langkah-langkah pengumpulan data sebagai berikut : (1). Wawancara mendalam (indepth interview). Wawancara dilakukan untuk mendapatkan informasi terkait identifikasi konflik dan pola negosiasi pada masyarakat Cek Bocek Salesek Reen Sury di Kabupaten Sumbawa. (2). Observasi partisipan (overt-participant) dilakukan untuk mengamati berbagai aktivitas dan perilaku individu-individu

33 C, Osi. Understanding Indigenous Dispute Resolution Processes And Western Alternative Dispute Resolution, Cultivating Culturally Appropriate Methods In Lieu Of Litigation. Cardozo J. Conflict Resol. 10, 2008, 200.

34 Behrens, 1992 dalam H. Adolf. Hukum Penyelesaian Sengketa Internasional. RajaGrafindo Persada: Bandung, 2004 
pada situasi konflik ${ }^{35}$. Narasumber yang dijadikan informan dalam proses pengumpulan data ini adalah individuindividu dalam struktur adat masyarakat Cek Bocek Salesek Reen Sury yang ditentukan secara purposif sesuai dengan kapasitasnya dalam membangun negosiasi pada konflik sengketa tanah yang dihadapinya. Penentuan narasumber ini disesuaikan dengan tujuan pemilihan sampel secara purposif dikarenakan peneliti memiliki pertimbangan khusus dalam menentukan dan menyeleksi sampel penelitian atas dasar kriteria-kriteria tertentu yang dibuat berdasarkan tujuan riset $^{36}$.

\section{PEMBAHASAN}

Di Kabupaten Sumbawa terdapat sekelompok masyarakat adat yang hidup secara turun temurun yang dikenal dengan masyarakat adat Cek Bocek Selesek Reen Sury, tepatnya di Desa Lawin, Kecamatan Ropang Kabupaten Sumbawa. Eksistensi mereka ditunjukkan dengan penggunaan budaya dan pranata adat sendiri, terutama penggunaan bahas yang berbeda dengan bahasa Sumbawa pada umumnya dikenal dengan bahasa "Berco"37. Pranata Adat adalah "Parenta Ne Adat", wilayah adat adalah wilayah Dodo, Selesek Sury, harta peninggalan/harta benda yang menjadi nilai sejarah kelompok adat Cek Bocek yakni berupa kekayaan keris, badik, peti, cangkir, Kre Alang, Kre Sesek, dompas, pedang, guci, dan lain sebagainya ${ }^{38}$. Masyarakat adat ini merupakan keturunan kesejarahan dari Dewa Datu Awan Mas Kuning dengan sistem pemerintahan adat saat ini dipimpin oleh Datu Sukanda RHD. Keberadaan

\footnotetext{
${ }^{35}$ R. Kriyantono. Teknik Praktis Riset Komunikasi. Kencana Prenadamedia Group: Jakarta, 2014, 111

${ }^{36}$ Ibid., 158

${ }^{37} \mathrm{~J}$. Gunawan. Op.Cit.

${ }^{38}$ L. Manca. Sumbawa Pada Masa Lalu (Suatu Tinjauan Sejarah). Cetakan I. Surabaya: Rinta Surabaya, 1984, 23
}

masyarakat adat Cek Bocek Selesek Reen Sury dipercaya telah hidup secara turun temurun sejak tahun 1512 sampai hari ini $^{39}$. Bahkan keberadaan masyarakat adat (indigenous people) secara umum diyakini telah hidup jauh sebelum terbentuknya Negara Kesatuan Republik Indonesia ${ }^{40}$

Masyarakat adat Cek Bocek Selesek Reen Sury secara administratif masuk dalam wilayah administrasi Desa Lawin dan Desa Lebangkar Kecamatan Ropang Kabupaten Sumbawa secara geografis mendiami pegunungan Sumbawa bagian selatan. Kesatuan Wilayah Adat Cek Bocek Selesek Rensury (Suku Berco) terletak dibagian tengah ke arah selatan dari wilayah Kabupaten Sumbawa dengan luasnya sebesar 28.975,74 Ha (289 km2) atau sekitar $3.46 \%$ dari luas Kabupaten Sumbawa 837.403,18 $\mathrm{Ha}^{41}$, seperti pada gambar dibawah ini :

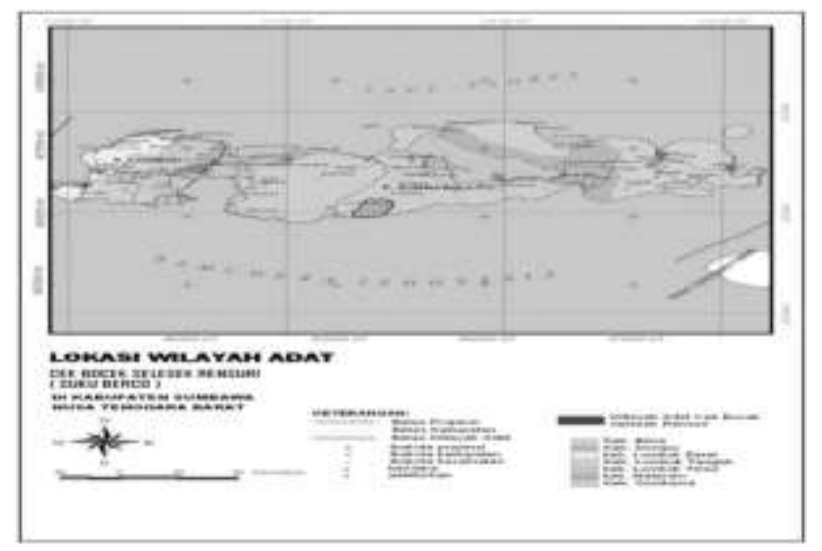

Gambar 2: Lokasi Wilayah Adat Masyarakat Cek Bocek Selesek Reen Sury ${ }^{42}$

Peneliti melihat telah terjadi dua sistem hukum yang di atas wilayah adat masyarakat Cek Bocek Salesek Reen Sury; pertama, hukum adat yang telah

\footnotetext{
${ }^{39}$ J. Gunawan. Op.Cit.

${ }^{40}$ T. M. Li. Masyarakat Adat, Difference, And The Limits of Recognition In Indonesia's Forest Zone. Modern Asian Studies 35(3), 2001 645-676.

${ }^{41}$ F. Aninidita. Masyarakat Adat Cek Bocek Selesek Reen Sury, Tak Diakui, Dirampok, Terancam, Laporan Sayogyo Institute, 2014, 42.

${ }^{42}$ Ibid.
} 
diberlakukan sejak lama dan dijaga keasliannya hingga hari ini dan kedua; hukum administratif negara yang menjadi lahan konsesi pertambangan PT. Newmont Nusa Tenggara. Dalam situasi ketidakpastian sistem hukum ini, keberadaan PT. Newmont Nusa Tenggara tidak mendapat sosial license dari masyarakat adat setempat sehingga timbul gejolak konflik dengan masyarakat lokal.

\section{Konflik Masyarakat Adat Cek Bocek Salesek Reen Sury dengan PT. Newmont Nusa Tenggara}

PT. Newmont Nusa Tenggara merupakan perusahaan patungan yang bergerak dalam bidang tambang dengan produk utama tembaga (cooper) yang sahamnya dimiliki oleh Nusa Tenggara Partnership (Nusa Tenggara Mining Corporation dan Sumitomo Corporation) memiliki saham mayoritas dari PT. NNT (80\%) dan yang mewakili perusahaan lokal yaitu PT Pukuafu Indah Indonesia memegang $20 \%$ dari keseluruhan saham dan PT Daerah Maju Bersaing (Perusahaan bersama Pemerintah Provinsi NTB, Pemerintah Kabupaten Sumbawa Barat, dan Kabupaten Sumbawa) ${ }^{43}$. Divestasi saham pada PT. DMB dilakukan secara bertahap hingga mencapai $31 \%$ pada tahun 2010. Namun adanya keinginan yang berbeda dan pihak-pihak yang tidak komitmen dalam kepemilikan saham bersama ini mempersulit kerjasama antar ketiga pemerintah daerah termasuk dengan pemerintah pusat.

Perjanjian Kontrak Karya (KK) didefinisikan sebagai perjanjian pengusahaan pertambangan antara Pemerintah Republik Indonesia dengan perusahaan swasta asing, Patungan Perusahaan asing dengan Indonesia dan

43 S. Wira \& L. Pria. Sinkronisasi Kebijakan Kerjasama Antar Daerah Dalam Divestasi Saham Pt Newmont Nusa Tenggara. Mimbar Hukum, 27(1), 2013. perusahaan swasta nasional untuk melaksanakan usaha pertambangan di luar minyak dan gas bumi ${ }^{44}$. Penandatanganan Kontrak Karya (KK) PT. Newmont Nusa Tenggara dilakukan pertamakali dengan pemerintah RI pada tahun 1986 untuk melakukan eksplorasi dan eksploitasi di dalam wilayah Kontrak Karya di Provinsi Nusa Tenggara Barat (NTB) yang didasari persetujuan Presiden Republik Indonesia nomor: B.43/Pres/II/1986, tanggal 2 Desember 1986, dengan luas hutan Dodo 97.204,60 ha. Sampai dengan tahun 2006, luas kontrak karya di Hutan Dodo mengalami penciutan menjadi 16.568,93 ha $^{45}$. Dalam kontrak karya tersebut PT. Newmont Nusa Tenggara mengajukan target area di Propinsi Nusa Tenggara Barat (NTB) dan membaginya menjadi Beberapa Blok. Untuk Blok Elang seluas $10.331 \mathrm{Ha}$ berada di wilayah adat Cek Bocek Selesek Rensury ${ }^{46}$.

Problem awal yang menjadi penyebab konflik antara masyarakat adat Cek Bocek Salesek Reen Sury dengan PT. Newmont Nusa Tenggara adalah penggunaan lahan atau wilayah adat mereka yang dipakai untuk keperluan ekplorasi PT. Newmont Nusa Tenggara tanpa sepengetahuan dan izin dari warga adat. Masyarakat adat Cek Bocek Salesek Reen Sury menilai kehadiran perusahaan mengganggu dan merusak ekosistem hutan dan kehidupan sosial budaya masyarakat. Meskipun telah banyak akademisi yang meneliti persoalan konflik sengketa tanah yang dihadapi oleh masyarakat adat Cek Bocek Salesek Reen

\footnotetext{
${ }^{44}$ J. Gunawan., dkk. 2011Cek Bocek, Rancangan Tata Ruang Wilayah Adat. Revisi ke-2, Mataram:

${ }^{45}$ Fahrunnisa, E. Soetarto \& N. K. Pandjaitan. Kontestasi Akses Sumber Agraria Di Kawasan Hutan Dodo Jaran Pusang, Kabupaten Sumbawa, Ntb Contestations Access To Agrarian Resources In Forest Area Of Dodo Jaran Pusang, Sumbawa District, NTB. Sodality. Jurnal Sosiologi Pedesaan, 4(2), 2016

${ }^{46}$ J. Gunawan., Op.Cit.
} NTB, 
Sury dan meyakini bahwa konflik telah terjadi pada masa-masa awal kehadiran PT. Newmont Nusa Tenggara.dan masih berlarut hingga hari ini ${ }^{47}$.

Berbagai cara ditempuh masyarakat adat untuk mendapatkan kembali hak atas tanah leluhur mereka, seperti surat yang dilayangkan pada tanggal 3 November 2008 dengan nomor surat $07 / \mathrm{CBRS} / \mathrm{X} / 2008$ perihal pemberitahuan kepada Gubernur NTB untuk tidak mengizinkan aktifitas eksplorasi yang dilakukan PT. Newmont Nusa Tenggara di wilayah adatnya ${ }^{48}$. Hal ini tentu karena tanah tersebut merupakan satu-satunya wilayah tempat mereka menggantungkan hidup untuk kehidupan ekonomi dan ritual adat masyarakat Cek Bocek Salesek Reen Sury. PT. Newmont Nusa Tenggara memasuki wilayah Blok Elang Dodo Rinti dan menggunakan tanah ulayat masyarakat dimulai pada tahun 19831986. Masuknya survei yang dilakukan perusahaan tersebut menghentikan akses masyarakat dengan ulayatnya yang dihentikan oleh pemerintah. Alasan pemerintah menghentikan akses masyarakat ke wilayah adatnya dikarenakan wilayah adat tersebut akan digunakan untuk survei pertambangan ${ }^{49}$.

${ }^{47}$ H.S. Salim \& I. Abdullah. Penyelesaian Sengketa Tambang: Studi Kasus Sengketa Antara Masyarakat Samawa Dengan Pt. Newmont Nusa Tenggara. Mimbar Hukum-Fakultas Hukum Universitas Gadjah Mada, 24(3), 2012, 476-488

I. Harianto. Sengketa Usaha Pertambangan di Wilayah Hutan Elang Dodo Kabupaten Sumbawa. Jurnal Magister Hukum Udayana, Udayana Master Law Journal, 2(1), 2013

F. Anindita. Masyarakat Adat, Penguasaan Hutan Adat dan Konsesi Pertambangan Masyarakat Adat Cek Bocek Vs Newmont Nusa Tenggara. Working Paper Sajogyo Institute. 2,2015

J. Gunawan. Op.Cit.

${ }^{48}$ Ibid.

49 F. Anindita. Masyarakat Adat, Penguasaan Hutan Adat dan Konsesi Pertambangan Masyarakat Adat Cek Bocek Vs Newmont Nusa Tenggara. Working Paper Sajogyo Institute. 2,2015

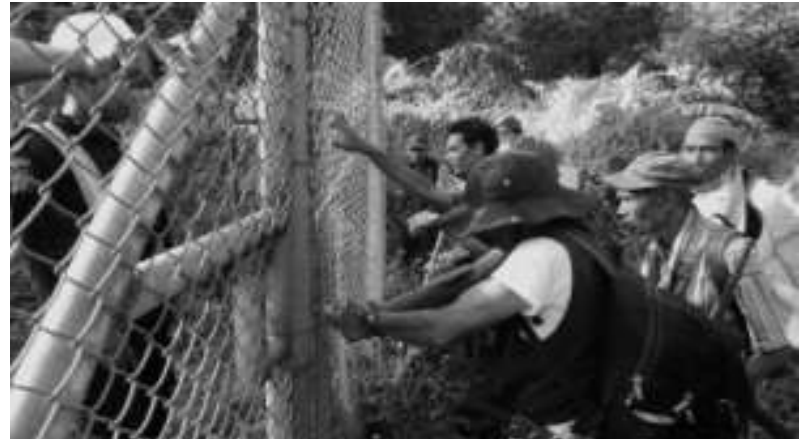

Gambar 3: Wilayah adat Masyarakat Cek Bocek Salesek Reen Sury yang dipagar PT. Newmont

Nusa Tenggara (Sumber Foto: AMAN Sumbawa)

Tertutupnya akses masyarakat dengan hutan adatnya memberikan dampak kerugian yang sangat besar bagi masyarakat adat, hal ini diakibatkan oleh produksi hasil gula yang berasal dari hutan adat terhenti. Pemerintah daerah yang diharapkan memberikan solusi seolah tutup telinga dan tidak mendengar protes yang dilakukan masyarakat. AZ menjelaskan bahwa intervensi yang dilakukan pemerintah daerah semakin memperburuk situasi dengan meminta masyarakat adat keluar dari wilayah adat mereka dengan alasan agar tidak mengganggu proses eksplorasi yang dilakukaan PT. Newmont Nusa Tenggara.

\section{Konflik Mayarakat Adat Cek Bocek Salesek Reen Sury Dengan Pemerintah Daerah Kabupaten Sumbawa}

Kuatnya dominasi Pemerintah Daerah yang memposisikan diri sebagai pihak yang paling menentukan arah pembangunan daerah semakin membuat rumit konflik yang terjadi. Sehingga, keberadaan masyarakat adat Cek Bocek Salesek Reen Sury seolah dikepung oleh dua pihak yang sama-sama memainkan peran dan kepentingan. Konflik dengan pemerintah daerah tidak lepas dari fungsinya sebagai regulator dan pelaksana aturan-aturan hukum yang berkaitan dengan pengakuan 
terhadap masyarakat adat di Kabupaten Sumbawa.

Lahirnya Peraturan Daerah No. 9 Tahun 2015 tentang Lembaga Adat Tana Samawa (LATS) melegitimasi Sultan Sumbawa sebagai pemimpin tunggal masyarakat adat di Kabupaten Sumbawa. Peraturan Daerah tersebut menjelaskan bahwa satu-satunya Lembaga adat di Sumbawa hanya Lembaga Adat Tana Samawa dan Sultan Sumbawa sebagai pemimpin adat Tau Tana' Samawa, serta mewakili masyarakat adat lainnya dalam urusan dengan pihak luar sehingga semakin tidak diberikan ruang atas keberadan masyarakat Adat Cek Bocek Selesek Reen Sury oleh Lembaga Adat Tana' Samawa (LATS) bersama Pemerintah Daerah dalam menuntut hak kepada PT. Newmont Nusa Tenggara.

Konflik dengan pemerintah daerah berarti juga konflik dengan Lembaga Adat Tana' Samawa (LATS) dan DPRD Kabupaten Sumbawa. Orang-orang yang menjabat struktural pada satu instansi juga menjabat/memiliki kekuasaan di instansi yang sama-sama memiliki kepentingan dalam urusan konflik antara masyarakat adat Cek Bocek Selesek Reen Sury dengan PT. Newmont Nusa Tenggara.

\section{Konflik Masyarakat Adat Cek Bocek Salesek Reen Sury Dengan Lembaga Adat Tana' Samawa (LATS)}

Konflik Masyarakat Adat dengan Lembaga Adat Tana' Samawa bermula sejak dilaksanakannya Musakara Adat yang dibarengi dengan pelantikan Sultan Sumbawa pada 5 April 2011. Pasca Musakara Adat, Sultan Sumbawa Muhammad Kaharuddin IV ditasbihkan oleh Pemerintah Daerah Sumbawa sebagai pemimpin tunggal masyarakat adat di Sumbawa. Sehingga yang terjadi kemudian adalah penolakan atas keberadaan masyarakat adat lainnya di Kabupaten
Sumbawa, termasuk masyarakat adat Cek Bocek Selesek Reen Sury.

Seperti tertuang dalam Titah Sultan Sumbawa yang dibacakan oleh ketua Lembaga Adat Tana' Samawa (LATS) Drs. H. Mahmud Abdullah dalam pertemuan bersama Masyarakat Adat Cek Bocek Selesek Reen Sury pada tanggal 15 Januari 2012 di gedung DPRD Kabupaten Sumbawa ${ }^{50}$. Titah tersebut berisi enam poin yang salah satunya berisi pengakuan kepada Lembaga Adat Tana' Samawa (LATS) sebagai satu-satunya Lembaga atau masyarakat adat yang berada di Kabupaten Sumbawa.

Kehadiran Lembaga Adat Tana' Samawa (LATS) buatan Pemerintah Daerah melalui Peraturan Daerah No. 9 Tahun 2015 tentang Lembaga Adat Tana' Samawa memunculkan konflik budaya yang melibatkan warga masyarakat Sumbawa melalui pernyataan Kesultanan Sumbawa yang disampaikan melalui Titah Sultan Sumbawa. Titah ini memancing reaksi kelompok-kelompok masyarakat adat di Kabupaten Sumbawa yang tidak mengakui kebudayaan dan keberadaan masyarakat adat lainnya.

\section{Model Negosiasi Masyarakat Adat Cek Bocek Salesek Reen Sury Pada Situasi Konflik}

Masyarakat adat dipercaya memiliki nilai-nilai khusus dalam berkomunikasi sebagai aspek penting dari kebudayaan yang telah diberlakukan secara turun-temurun disebut sebagai deliberate instruction, yaitu pola komunikasi dengan cara instruksi langsung yang diberikan oleh sesepuh desa (kelompok) pada anggota lainnya terkait bagaimana berperilaku dan bertindak seperti memasak, beternak dan menanam ${ }^{51}$. Konflik

\footnotetext{
${ }^{50} \mathrm{~J}$. Gunawan. Op.Cit.

${ }^{51}$ Warren (1994) dalam P. Mundy \& L. Compton. Indigenous Communication And Indigenous
} 
internal dalam tubuh masyarakat adat Cek Bocek Salesek Reen Sury selama ini masih bisa diatasi secara adat melalui kegiatan Rapulung. Selama warga adat mematuhi peraturan-peraturan adat, selama itu juga mereka disebut dan diakui sebagai bagian dari masyarakat adat Cek Bocek Salesek Reen Sury:

Sebelum terjadinya konflik, komunikasi eksternal ke luar kelompok masyarakat adat hampir tidak pernah dilakukan selain dengan PT. Newmont Nusa Tenggara. Konflik semakin rumit setelah intervensi Pemerintah Daerah dan kehadiran Lembaga Adat Tana' Samawa (LATS).

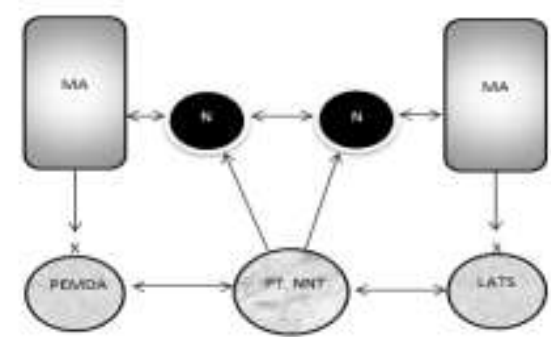

Gambar 4: Model Komunikasi Masyarakat Adat Cek Bocek Salesek Reen Sury

Gambar di atas menjelaskan model negosiasi masyarakat adat Cek Bocek Salesek Reen Sury dalam situasi konflik. Intervensi Pemerintah Daerah menyulitkan masyarakat adat dalam membangun komunikasi serta tertutupnya akses bagi kelompok yang tidak diakui keberadaannya sebagai masyarakat adat di Kabupaten Sumbawa. Pemerintah Daerah Kabupaten Sumbawa sebagai regulator idealnya menjadi agen demokrasi dan menjalankan komunikasi two-way symmetrical yang menekankan pentingnya perubahan dalam merespon tuntutan publik ${ }^{52}$. Ditambah lagi

Knowledge. Development Communication Report, 1991. 74(3), 1-3.

52 J. E. Grunig and L. A. Grunig, L.A 1992. Excellence in Public Relations and Communication Management. Hillsdale, NJ : Lawrence Erlbaum Associates. dengan kehadiran Lembaga Adat Tana' Samawa (LATS) yang mereduksi sisi budaya masyarakat adat. Namun, nilai-nilai dan kekuatan budaya menjadi pemersatu masyarakat adat Cek Bocek Salesek Reen Sury dalam menghadapi situasi konflik sengketa yang dihadapinya.

Di negara-negara Barat, digunakan sebuah model negosiasi well specified dengan pendekatan negosiasi secara langsung (direct confrontation) sering digunakan dan menjadi bagian awal dalam model ini yang akan melibatkan banyak aspek budaya ${ }^{53}$. Pendekatan direct confrontation telah dilakukan oleh masyarakat adat Cek Bocek Salesek Reen Sury dalam konflik sengketa yang dihadapinya dengan PT. Newmont Nusa Tenggara. Akibat dari konfrontasi ini, masyarakat kehilangan tanah areal kuburan tua leluhur mereka sebagai konsekuensi model negosiasi dengan pendekatan direct confrontation ${ }^{54}$.

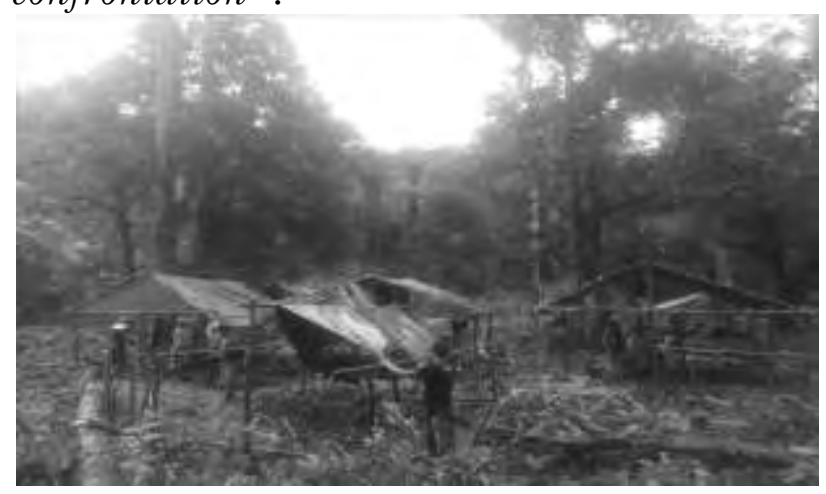

Gambar 5: Suasana Warga Menjaga Wilayah Adat(Sumber: Dokumen Pribadi)

Gambar di atas memperlihatkan beberapa warga adat sedang mendirikan tenda untuk menghadapi konfrontasi langsung dengan PT. Newmont Nusa Tenggara yang masih bersitegang sampai hari ini. Selain itu, penting juga dilihat bahwa kepercayaan yang dimiliki oleh

53 J. M. Brett. Culture and negotiation. International journal of psychology, 2000. 35(2), 97104.

${ }^{54}$ Ibid. 
individu satu sama lain menjadi dasar efektifitas sebuah organisasi atau kelompok. Kepercayaan ini memiliki efek secara langsung atau tidak langsung yang dapat dilihat dari kinerja, komitmen organisasi dan kepercayaan individu untuk tetap menjadi bagian dari kelompoknya ${ }^{55}$. Kepercayaan ini tidak datang secara alami, namun harus disusun dan dikelola dengan hati-hati karena tingkat kepercayaan dapat mengurangi perilaku opportinustic serta gesekan-gesekan setiap individu ${ }^{56}$.

\section{Negotiation Intermediaries Dalam Konflik Sengketa Hak Atas Tanah Masyarakat Cek Bocek Salesek Reen Sury}

Dalam teori negosiasi, terdapat satu pola yang dapat dilakukan melalui perantara pihak ketiga disebut intermediaries communication $^{57}$. Pola ini dapat dilakukan jika pihak-pihak terkait dirasa perlu untuk melakukan kontak informal dengan pihak lain. Berikut model pendekatan intermediaries communication Lewicki, Saunders dan Barry ${ }^{58}$.

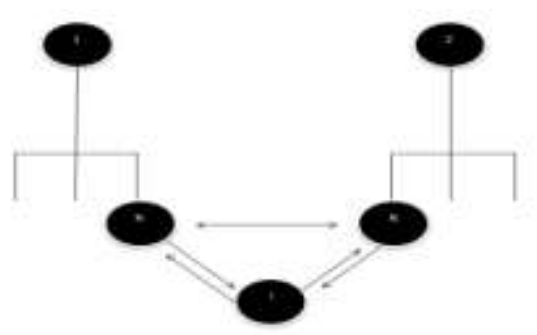

Gambar 6: Communicate Through

Intermediaries (Lewicki, Saunders \& Barry, 2006, h. 319)

${ }^{55}$ D.L. Ferrin, K.T. Dirks \& P.P. Shah. Direct and indirect effects of third-party relationships on interpersonal trust. Journal of applied psychology, 2006. 91(4), 870.

${ }^{56}$ R. J. Lewicki \& B.B. Bunker. Developing and maintaining trust in work relationships. Trust in organizations: Frontiers of theory and research,1996. 114, 139

57 R.J. Lewicki, B. Saunders and B. Barry. Negotiation (5th Ed.). New York: Mcgraw-Hill Higher Education. 2006

${ }^{58}$ Ibid.
Tujuan negosiasi adalah untuk menciptakan sesuatu yang baru yang tidak dilakukan sebelumnya atau untuk menyelesaikan masalah atau sengketa antara kedua pihak ${ }^{59}$. Dari penjelasan tersebut, dapat dikatakan bahwa negosiasi adalah upaya yang dilakukan antara pihak-pihak yang berkonflik dengan tujuan mencari jalan keluar untuk menyelesaikan pertentangan berdasarkan kesepakatan bersama. Pendekatan intermediaries communication dilakukan oleh pihak ketiga melalui kontak eksternal dan dapat berfungsi sebagai saluran komunikasi. Kemudian pada saat yang bersamaan, ikatan ini juga menyiratkan kesamaan posisi, kesetaraan derajat untuk saling mengontrol dan mempengaruhi perilaku individu yang lain $^{60}$.

Intermediaries communication biasanya dipilih berdasarkan pengalaman atau ikatan masa lalu, persahabatan pribadi, reputasi, memiliki kredibilitas, tingkat kepercayaan yang tinggi dan memiliki integritas ${ }^{61}$. Pendekatan intermediaries communication sering digunakan dalam situasi ketika negosiasi kedua pihak menemui jalan buntu atau ketika negosiasi kedua pihak tidak berjalan dengan baik. Sehingga pihak yang bersengketa membutuhkan kehadiran pihak ketiga yang diharapkan dapat membantu menyelesaikan masalahnya. Negosiasi sebagai sebuah fenomena yang luas dan dapat terjadi pada siapapun yang digambarkan sebagai proses yang lahir dari peristiwa konflik, namun negosiasi juga dapat menjadi resolusi konflik untuk

${ }^{59}$ R.J. Lewicki, B. Barry, D. M. Saunders, J. W. Minton. Negotiation (4th Ed.). New York: McgrawHill Higher Education. 2003.

60 R. M. Emerson. Power-Dependence Relations. American Sociological Review, 1962. 31-41.

${ }^{61}$ R.J. Lewicki, B. Saunders and B. Barry. 2006. Negotiation (5th Ed.). New York: Mcgraw-Hill Higher Education 
menyelesaikan masalah secara alami dan tanpa kekerasan ${ }^{62}$.

Dalam proses komunikasi, baik verbal dan nonverbal, sangat penting untuk mencapai tujuan negosiasi dalam menyelesaikan sebuah konflik. Melalui komunikasi, negosiasi dapat digunakan sebagai alat untuk mengidentifikasi dan membangun hubungan diantara pihak-pihak yang berkonflik ${ }^{63}$. Termasuk dalam mengatur strategi atau menemukan alternatif solusi dalam mencapai tujuan dan kesepakatan. Berikut pola komunikasi masyarakat adat Cek Bocek Salesek Reensury menggunakan pendekatan intermediaries communication:

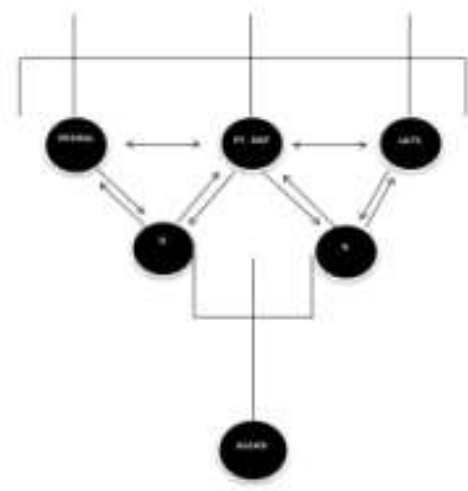

Gambar 7: Pola Komunikasi Intermediaries Masyarakat Adat Cek Bocek Salesek Reen Sury

Dalam konflik sengketa masyarakat adat Cek Bocek Salesek Reen Sury yang menggunakan Aliansi Masyarakat Adat Nusantara Daerah Sumbawa (AMAN) dalam membangun komunikasi dengan pihak terkait dan menjadikan AMAN sebagai satu-satunya juru bicara atau media komunikasi pihak eksternal kepada masyarakat adat. Perbedaan utama dalam proses negosiasi yang terjadi antara negosiator adanya perbedaan kepentingan,

${ }^{62}$ D.G. Pruitt \& J.Z. Rubin. 1986. Social Conflict: Escalation, Impasse, And Resolution. Reding, MA: Addision-Wesley.

${ }^{63}$ L.L. Putnam \& J.P. Folger. 1988. Communication, Conflict, And Dispute Resolution The Study Of Interaction And The Development Of Conflict Theory. Communication Research, 15(4), 349-359. perbedaan pendapat, menghidari resiko dan perbedaan prefensi waktu ${ }^{64}$. Negosiasi dalam prosesnya dapat menjelaskan dan persamaan situasi selama konflik berlangsung. Apalagi semua orang berusaha mempertahankan budayanya dalam berbagai siuasi komunikasi. Dalam variabilitas budaya atau individu dapat mempengaruhi sebuah pilihan, cara dan strategi penanganan sengketa ${ }^{65}$.

\section{SIMPULAN}

Pola negosiasi dan komunikasi dengan mengedepankan silaturahmi dan itikad baik serta komitmen kuat dari masing-masing pihak mutlak diperlukan dalam rangka penyelesaian serta pencapaian masingmasing pihak bersengketa. Hasil penelitian menunjukkan bahwa, masalah yang dihadapi oleh Masyarakat Adat Cek Bocek Salesek Reen Sury di Kabupaten Sumbawa tidak semata berkonflik dengan PT. Newmont Nusa Tenggara. Desentralisasi dan kuatnya dominasi Pemerintah Daerah Kabupaten Sumbawa semakin memperumit situasi, terlebih dengan hadirnya Lembaga Adat Tana' Samawa (LATS) sebagai perpanjangan tangan Pemerintah Daerah saat berbicara budaya dan situasi adat di Kabupaten Sumbawa. Konflik masyarakat adat yang semula berhadapan dengan PT. Newmont Nusa Tenggara berkembang lebih besar dan melibatkan Pemerintah Daerah Kabupaten Sumbawa sebagai regulator dari kebijakan-kebijakan daerah, Lembaga Adat Tana Samawa (LATS) menciptakan konflik budaya dengan masyarakat adat Cek Bocek Salesek Reen Sury dan masyarakat adat lainnya di Kabupaten Sumbawa. Ternyata

${ }^{64}$ R.J. Lewicki. B. Barry. D.M. Saunders, J.W. Minton. 2003. Negotiation (4th Ed.). New York: Mcgraw-Hill Higher Education

65 J.G. Oetzel \& S. Ting-Toomey. 2003. Face Concerns In Interpersonal Conflict A Cross-Cultural Empirical Test of The Face Negotiation Theory. Communication Research, 30(6), 599-624. 
regulasi mengenai masyarakat adat dalam urusan pertanahan tidak dijalankan sepenuhnya oleh pemerintah daerah kabupaten sumbawa.

Konflik urusan pertanahan yang melibatkan perangkat daerah pada masyarakat adat Cek Bocek Salesek Reen Sury dan PT. Newmont Nusa Tenggara di Kabupaten Sumbawa selama ini tidak mengarah pada conflict resolution. Konsep pola komunikasi intermediaries diharapkan mampu mengurai persoalan-persoalan konflik melalui negosiasi dengan keterlibatan pihak ketiga.

\section{DAFTAR PUSTAKA}

Adolf, H. 2004. Hukum Penyelesaian Sengketa Internasional. Bandung: RajaGrafindo Persada.

Anindita, F .2014. Masyarakat Adat Cek Bocek Selesek Reen Sury, Tak Diakui, Dirampok, Terancam, Laporan Sayogyo Institute, 2014, hlm 42.

Anindita. F. 2015. Masyarakat Adat, Penguasaan Hutan Adat dan Konsesi Pertambangan Masyarakat Adat Cek Bocek Vs Newmont Nusa Tenggara. Working Paper Sajogyo Institute2: 1-24.

Badan Pertanahan Nasional Republik Indonesia. 2017.Layanan Public Program Penanganan Kasus Pertahanan. Diakses Pada 27 Januari 2017.

< http://www.bpn.go.id/layananpublik/program/penanganan-kasuspertanahan $>$.

Bedner, A, dan Van Huis, S. 2008. The Return of The Native In Indonesian Law: Indigenous Communities In Indonesian Legislation. Bijdragen Tot De Taal-, Land-En Volkenkunde: Journal of The Humanities And Social Sciences Of Southeast Asia 164(2): 165193.
Brett, J. M. 2000. Culture And Negotiation. International Journal of Psychology 35(2): 97-104.

Budiman, E. 2005. Peradilan Agraria Solusi Alternatif Penyelesaian Sengketa Agraria. Jurnal Hukum, (01) 1, 74-81

Butt, S., David, N., dan Laws, N. 2009. Looking Forward: Local Dispute Resolution Mechanisms In Timor Leste: Australian Legal Resources International 09/33: 121.

Davidson, J, dan Henley, D. 2007. The Revival of Tradition In Indonesian Politics: The Deployment of Adat From Colonialism To Indigenism. New York: Routledge.

Driscoll, J. W. 1978. Trust And Participation In Organizational Decision Making As Predictors Of Satisfaction: The Academy Of Management Journal 21(1): 44-56.

Emerson, R, M. 1962. Power-Dependence Relations:American Sociological Review: 31-41.

Erari, P. K. 1999. Tanah Kita, Hidup Kita: Hubungan Manusia Dan Tanah Di Irian Jaya Sebagai Persoalan Teologis: Eko Teologi Dalam Prespektif Melanesia. Pustaka Sinar Harapan.

Fahrunnisa, Soetarto, E., \& Pandjaitan, N. K. (2016). Kontestasi Akses Sumber Agraria Di Kawasan Hutan Dodo Jaran Pusang, Kabupaten Sumbawa, Ntb Contestations Access To Agrarian Resources In Forest Area Of Dodo Jaran Pusang, Sumbawa District, Ntb. Sodality: Jurnal Sosiologi Pedesaan, 4(2).

Ferrin, D. L., Dirks, K. T., dan Shah, P. P. 2006. Direct And Indirect Effects Of Third-Party Relationships On Interpersonal Trust. Journal of Applied Psychology 91(4): 870. 
Grunig, J, E. 1992. Excellence in public relations and communications management. New Jersey: Lawrence Erlbaum Associates inc. Publishers.

Gunawan, J. 2011, Cek Bocek, Rancangan Tata Ruang Wilayah Adat. Cetak Kedua, Mataram: AMAN PRESS.

Gunawan, J. 2015. Implementasi Permendagri N0 52 Tahun 2014 Tentang Pedoman Pengakuan Dan Perlindungan Masyarakat Hukum Adat (Studi Terhadap Keberadaan Masyarakat Adat Cek Bocek Selesek Reen Suri Di Kabupaten Sumbawa). Tesis, Mataram: Program Pascasarjana Unram.

Harianto, I. 2013. Sengketa Usaha Pertambangan di Wilayah Hutan Elang Dodo Kabupaten Sumbawa.Jurnal Magister Hukum Udayana (Udayana Master Law Journal), 2(1).

Kriyantono, R. 2014. Teknik Praktis Riset Komunikasi. Jakarta: Kencana Prenadamedia Group

Kurnia, T. 2007. The Struggle Over Land Rights: A Study Of Indigenous Property Rights In Indonesia. Disertasi, Washington: University Of Washington.

Lewicki, R, J. Barry, B. Saunders, Barry, B. 2006. Negotiation $5^{\text {th }}$ ed, New York: Mcgraw-Hill Higher Education.

Lewicki, R, J. Barry, B. Saunders, D, M. Minton, J, W. 2003. Negotiation $4^{\text {th }}$ ed, New York: Mcgraw-Hill Higher Education.

Lewicki, R. J., dan Bunker, B. B. 1996. Developing And Maintaining Trust In Work Relationships. Trust In Organizations: Frontiers Of Theory And Research: 114- 139.

Li, T, M. 2001. Masyarakat Adat, Difference, And The Limits Of
Recognition In Indonesia's Forest Zone. Modern Asian Studies 35(3): 645676.Mcgraw-Hill Higher Education.

Mu'adi, S. 2008. Penyelesaian Sengketa Hak Atas Tanah Perkebunan Melalui Cara Non Litigasi (Suatu Studi Litigasi Dalam Situasi Transisional. Disertasi, Semarang: Program Pasca Sarjana Universitas Diponegoro.

Mundy, P., \& Compton, L. (1991). Indigenous Communication And Indigenous Knowledge. Development Communication Report, 74(3), 1-3.

Oetzel, J. G, dan Ting-Toomey, S. 2003. Face Concerns In Interpersonal Conflict A Cross-Cultural Empirical Test Of The Face Negotiation Theory: Communication Research 30 (6): 599-624.

Osi, C. 2008. Understanding Indigenous Dispute Resolution Processes And Western Alternative Dispute Resolution, Cultivating Culturally Appropriate Methods In Lieu Of Litigation. Cardozo J. Conflict Resol., 10, 163.

Pruitt, D, G, dan Rubin, J. Z. 1986. Social Conflict: Escalation, Impasse, And Resolution. Reding: Addision-Wesley.

Putnam, L. L, dan Folger, J, P. 1988. Communication, Conflict, And Dispute Resolution The Study Of Interaction And The Development Of Conflict Theory: Communication Research 15(4): 349-359.

Sakai, M. 2002. Land Dispute Resolution In The Political Reform At The Time Of Decentralization In Indonesia. Antropologi Indonesia, 68, 40-56.

Salacuse, J, W. 2007. Is There A Better WayAlternative Methods Of Treaty-Based, 
Investor-State

Dispute

Resolution: Fordham Int'l Lj 31: 138.

Spradley, J, P. 2016. The Ethnographic Interview. United State of America: Waveland Press.

Wehrmann, B. 2008. Land Conflicts: A Practical Guide To Dealing With Land Disputes. Eschborn: Gtz

\section{Jurnal}

Larson, A, M. 2012. Measuring A Company Reputation In A Crisis Situation: An Ethnography Approach On The Situational Crisis Communication Theory. International Jounal of Business and Social Science 3(9). 214-223

Rachman, N, F. dan Siscawati, M. 2014. Masyarakat Hukum Adat Adalah Bukan Penyandang Hak, Bukan Subjek Hukum, dan Bukan Pemilik Wilayah Adatnya: Wacana Jurnal Transformasi Sosial 33: 3-23.

Salim, H. S., \& Abdullah, I. 2012. Penyelesaian Sengketa Tambang: Studi Kasus Sengketa Antara Masyarakat Samawa Dengan Pt. Newmont Nusa Tenggara. Mimbar Hukum-Fakultas Hukum Universitas Gadjah Mada, 24(3), 476-488.DOI: 10.22146/jmh.407

Whiteman, G, dan Mamen, K. 2002. Examining Justice And Conflict Between Mining Companies And Indigenous Peoples Cerro Colorado And The Ngabe-Bugle In Panama: Journal Of Business And Management 8 (3): 293.

Wira, S, dan Pria, L. 2015. Sinkronisasi Kebijakan Kerjasama Antar Daerah Dalam Divestasi Saham PT Newmont Nusa Tenggara: Mimbar Hukum 27 (1). 